\title{
HUBUNGAN TEMPERATUR/SUHU TUBUH, TEKANAN DARAH TERHADAP TEKANAN INTRA KRANIAL (TIK) PADA KLIEN STROKE HEMORAGIK DI RSU KABUPATENTANGERANG
}

\author{
Sunardi*
}

\begin{abstract}
Abstrak
Peningkatan Tekanan Intrakranial (TIK) merupakan kedaruratan yang harus diatasi dengan segera. Fenomena sekunder disebabkan gangguan sirkulasi, edema cerebral hingga menyebabkan kematian. Beberapa faktor yang mempengaruhi terjadinya TIK, adalah jaringan otak, darah dan cairan serebrospinal (CSF), faktor lain diantaranya tekanan arteri, tekanan vena, tekanan intraabdominal \& thorak, suhu tubuh dan gas darah, (Kostic et al, 2011). Perubahan TIK lebih banyak dipengaruhi oleh sirkulasi serebral atau cerebral blood flow (CBF), menurut Patria et al, (2006). rata-rata bila terjadi peningkatan $\mathrm{pCO}_{2} 1$ (satu) $\mathrm{mmHg}$ dimungkinkan terjadi peningkatan darah 1-2 cc pada cerebral blood flow, ini akan terjadi perubahan peningkatan volume darah di otak hingga menyebabkan peningkatan TIK. Penelitian ini bertujuan untuk mengidentifikasi hubungan suhu tubuh, tekanan darah terhadap adanya perubahan intrakranial pada klien stroke hemoragik. Design penelitian adalah korelasi dengan pendekatan cross sectional. Penelitian dilakukan pada bulan November - Desember 2016 di RSU Kabupaten Tangerang dengan populasi penelitian adalah Klien stroke hemoragik yang dirawat di RSU Kabupaten Tangerang, sampel yang memenuhi kriteria sebanyak 14 responden. Hasil penelitian menunjukan bahwa suhu tubuh tidak mempengaruhi perubahan tekanan intrakranial pada klien stroke hemoragik dengan nilai $\quad p: 0,123(\alpha=0,05)$, sedangkan tekanan darah sistolik berhubungan dengan terjadinya peningkatan tekanan intrakranial pada pasien stroke hemoragik dengan nilai $p$ sebesar $0,005(\alpha=0,05)$, tekanan diastolik tidak berhubungan dengan terjadinya peningkatan tekanan intrakranial pada pasien stroke hemoragik di RSU Kabupaten Tanggerang dengan nilai $p: 0,240(\alpha=0,05)$. Hasil ini merekomendasikan pentingnya observasi atau pemantauan terhadap perubahan TIK, sehingga dapat dideteksi adanya perubahan TIK.
\end{abstract}

Kata kunci : Stroke, Temperatur/suhu tubuh, Tekanan darah

*) Dosen Jurusan Keperawatan Poltekkes Kemenkes Banten 


\title{
RELATIONS BODY TEMPERATURE, BLOOD PRESSURE AGAINST INTRA CRANIAL PRESSURE (ICP) IN HAEMORRHAGIC STROKE CLIENTS IN RSU KABUPATENTANGERANG
}

\begin{abstract}
Sunardi
Abstract

Increased Intracranial Pressure (ICP) is an emergency that must be addressed immediately. Secondary phenomenon caused by impaired circulation and edema that can lead to death. Some of the factors that influence the occurrence of ICP, namely brain tissue, blood and cerebrospinal fluid (CSF), other factors affecting the intracranial pressure that is; arterial pressure, venous pressure, intra-abdominal and thoracic pressure, body temperature and blood gases, (Kostic et al, 2011). Changes in ICP is more influenced by the cerebral circulation or cerebral blood flow (CBF), according to Patria et al, (2006). average when there is an increase pCO2 $1 \mathrm{mmHg}$ possible increased 1-2 $\mathrm{cc}$ of blood in the cerebral blood flow and this will increase blood volume changes in the brain can be increased ICP. This study aimed to identify the relationship of body temperature, blood pressure to the change in the intracranial hemorrhagic stroke clients. Design research is the correlation with cross sectional approach. The study was conducted in November-December 2016, the Tangerang District General Hospital study population are clients of hemorrhagic stroke who were treated in RSU KabupatenTangerang, samples that meet the criteria as much as 14 respondents. Results showed that the body temperature does not affect changes in intracranial pressure in hemorrhagic stroke clients with p value: $0.123(\alpha=0.05)$, whereas systolic blood pressure associated with an increase in intracranial pressure in patients with hemorrhagic stroke with $p$ value of $0.005(\alpha=0,05)$, diastolic pressure was not associated with an increase in intracranial pressure in patients with hemorrhagic stroke in Tangerang District Hospital with $p$ value: $0.240(\alpha=0.05)$. results research recommended observed is important to detection for change ICP.
\end{abstract}

Key words: Stroke, Body Temperature, Blood pressure

*) Lecture Jurusan Keperawatan Poltekkes Kemenkes Banten 


\section{Pendahuluan}

Di Indonesia jumlah klien stroke diperkirakan meningkat setiap tahunnya, Riskesdas Tahun 2007, menunjukan kasus stroke dimasyarakat yang terdeteksi yaitu $85,7 \%$ dan prevalensi stroke pada perempuan lebih tinggi dari pada laki-laki. Pada hasil Riskesdas tahun 2013 kasus stroke berdasarkan wawancara (responden pernah terdiagnosis dan mengalami gejala) juga meningkat dari 8,3 per 1000 (2007) menjadi 12,1 per 1000 (2013), dari datadata diatas menunjukan angka prevalensi stroke meningkat pada tiap tahunnya.

Fenomena di klinik klien stroke akut kadang disertai TIK yang meningkat, biasanya TIK meningkat disertai perubahan suhu tubuh dan tekanan darah. Perubahan TIK tergantung adanya perubahan dari diameter CSF, Sirkulasi serebral "Cerebral Blood Flow" (CBF) dan abnormalitas intrakranialnya, (Stocchetti et al. 2013). Otak mendapat 20\% dari curah jantung artinya aliran darah secara global serebral dialiri volume darah per menit per 100 gram jaringan otak, rata-rata bila terjadi peningkatan tekanan kadar $\mathrm{CO}_{2}(p C O 2) 1$ mmHg dimungkinkan terjadi peningkatan darah 1-2 cc pada CBF dan ini akan terjadi perubahan peningkatan volume darah di otak (Black \& Hawk, 2014).

Tekanan darah dan suhu tubuh merupakan salah satu interpretasi autoregulasi dari TIK yang dapat dimonitor setiap saat, ketika Tekanan darah meningkat terjadi kontriksi pembuluh darah otak sehingga kebutuhan oksigen berkurang, ketika tekanan darah tinggi sekali pembuluh darah otak akan dilatasi aliran darah ke otak menjadi meningkat, (Honig et al. 2015). Sedangkan suhu tubuh pertama kali berpengaruh terhadap metabolisme, dimana regulasi metabolisme tergantung pada perubahan Oksigen $\left(\mathrm{O}_{2}\right)$ dan Carbondiaksida $\left(\mathrm{CO}_{2}\right)$, ketika $\mathrm{O}_{2}$ rendah dan $\mathrm{CO}_{2}$ tinggi menyebabkan vasodilatasi regulasi CSF, dimana produksi CSF menurun atau meningkatkan reabsorpsi CSF sehingga dapat meningkatkan dan menurunkan TIK, (Helleberg et al. 2014). tetapi suhu tubuh dan tekanan darah berapa derajat yang dapat meningkatan TIK ini masih menjadi fenomena.

TIK yang meningkat akan menimbulkan banyak masalah terhadap klien yang mengalami stroke akut, dampak adanya perubahan TIK diantaranya penurunan kesadaran, sakit kepala, ganguan penglihatan dan muntah proyektil, dampak paling berbahaya dengan perubahan TIK adalah adanya herniasi otak, (AHA, 2015).

Hasil penelitian ini bertujuan untuk mengidentifikasi hubungan tekanan darah, suhu tubuh terhadap tekanan intrakranial pada klien stroke hemoragik/perdarahan di RSU KabupatenTangerang terkait hal tersebut. 


\section{Metode Penelitian}

Penelitian ini merupakan penelitian korelasi dengan pendekatan cross sectional design. Penelitian bertujuan untuk mengidentifikasi hubungan tekanan darah, suhu tubuh terhadap tekanan intrakranial pada klien stroke hemoragik/perdarahan di RSU Kabupaten Tangerang, sesuai Pollit (2006).

Populasi adalah klien Stroke hemoragik yang dirawat diruang rawat RSU KabupatenTangerang, Dan berdasarkan populasi kasus stroke hemoragik yang dirawat di ruang rawat RSU Kabupaten Tangerang pada tahun 2015 sebanyak 117 orang, dan sampel adalah sebanyak 14 orang, yang telah memenuhi kriteria inklusi dan eklusi.

\section{Hasil}

Hasil analisis univariat menunjukan jumlah responden paling banyak adalah berjenis kelamin perempuan dengan jumlah 8 dari 14 orang $(57,1 \%)$ dan responden berjenis kelamin laki-laki berjumlah 6 orang $(42,9 \%)$. Sedangkan rata-rata umur responden adalah 48,93 tahun dengan simpangan baku sebesar 7,022, dan diyakini 95\% responden berusia antara 44,87 tahun sampai dengan 52,98 tahun, dimana responden dengn umur minimal 34 tahun \& umur maksimal 58 tahun.

Hasil univariat rata-rata suhu tubuh responden adalah $36,71^{\circ} \mathrm{C}$ dengan standar deviasi 0,59 , dan diyakini $95 \%$ suhu tubuh responden dalam rentang 36,37 sampai dengan 37,05 hal ini menunjukan bahwa suhu tubuh responden dalam kategori normal. Rata-rata tekanan darah sistolik sebesar 147,86 $\mathrm{mmHg}$ dengan standar deviasi 17,17, dan diyakini 95\% tekanan sistolik dalam rentang $137,94 \quad \mathrm{mmHg}$ sampai dengan 157,77 $\mathrm{mmHg}$, hal ini menunjukan tekanan sistolik sebagian besar mengalami peningkatan dari normal. Sedangkan rata-rata tekanan darah diastolik sebesar 92,86 $\mathrm{mmHg}$ dengan standar deviasi 6,11, dan diyakini 95\% tekanan diastolik dalam rentang $89,33 \mathrm{mmHg}$ sampai dengan 96,39 $\mathrm{mmHg}$, hasil ini menunjukkan bahwa dalam rentang normal. Sedangkan hasil analisis univariat dari 14 responden sebagian besar tidak mengalami peningkatan tekanan intrakranial sebanyak 13 dari 14 orang $(92,9 \%)$.

Pada hasil analisis bivariat menjelaskan mengenai hubungan suhu tubuh, tekanan darah terhadap TIK pada klien stroke hemoragik. Analisis dengan menggunakan uji statistik independen sample t-Test (Pooled $t$ test). Jenis uji tersebut digunakan setelah dilakukan uji kenormalan data menggunakan Sapiro wilk, dengan nilai $p>\alpha(0,05)$, semua data variabel tersebut berdistribusi normal, yang merupakan salah satu syarat uji statistik parametrik. 
Tabel 1: Hubungan Suhu Tubuh dengan Tekanan Intrakranial pada Klien Stroke Hemoragik di RSU Kabupaten Tangerang $(n=14)$

\begin{tabular}{|l|l|c|c|c|c|c|}
\hline No & $\begin{array}{c}\text { Tekanan Intrakranial } \\
\text { (TIK) }\end{array}$ & $\mathbf{N}$ & Mean & SD & t & P value \\
\hline 1 & Meningkat & 1 & 37,60 & 0,55 & 1,657 & 0,123 \\
\hline 2 & Tidak Meningkat & 13 & 36,64 & & \\
\hline
\end{tabular}

Pada tabel 1 diketahui bahwa rata-rata suhu tubuh pada responden dengan TIK meningkat sebesar $37,6^{\circ} \mathrm{C}$ dan TIK tidak meningkat rata-rata sebesar 36,64 dengan standar deviasi 0,55.
Dapat disimpulkan bahwa suhu tidak mempengaruhi perubahan TIK pada klien stroke hemoragik dengan nilai $p$ sebesar $0,123(\alpha=0,05)$.

Tabel 2: Hubungan Tekanan Darah Sistolik dengan Tekanan Intrakranial pada Klien Stroke Hemoragik di RSU Kabupaten Tangerang $(n=14)$

\begin{tabular}{|l|l|c|c|c|c|c|}
\hline No & Tekanan Intrakranial & N & Mean & SD & t & P value \\
\hline 1 & Meningkat & 1 & 190 & \multirow{2}{*}{12,65} & 3,445 & 0,005 \\
\hline 2 & Tidak Meningkat & 13 & 144,2 & & & \\
\hline
\end{tabular}

Berdasarkan tabel 2 diketahui bahwa rata-rata tekanan darah sistolik pada klien dengan TIK meningkat sebesar 190 $\mathrm{mmHg}$, dan tekanan darah sistolik pada klien yang TIK tidak meningkat rata-rata 144,2 mmHg dengan standar deviasi 3,445. Hasil iini menunjukan bahwa tekanan darah sistolik lebih tinggi pada klien dengan TIK meningkat. Tekanan darah sistolik berhubungan dengan terjadinya peningkatan TIK pada klien stroke hemoragik di RSU Kabupaten Tanggerang dengan nilai $p$ sebesar 0,005 $(\alpha=0,05)$.

Tabel 3: Hubungan Tekanan Darah Diastolik dengan Tekanan Intrakranial pada Klien Stroke Hemoragik di RSU Kabupaten Tangerang $(n=14)$

\begin{tabular}{|l|l|l|l|l|l|l|}
\hline No & Tekanan Intrakranial & $\mathbf{N}$ & Mean & SD & t & P value \\
\hline 1 & Meningkat & 1 & 100 & 5,991 & 1,237 & 0,240 \\
\hline 2 & Tidak Meningkat & 13 & 92,31 & & \\
\hline
\end{tabular}

Sedangkan Tabel 3 menunjukan rata-rata tekanan darah diastolik pada klien dengan TIK meningkat sebesar $100 \mathrm{mmHg}$, dan tekanan darah diastolik pada klien yang
TIK tidak meningkat rata-rata $92,31 \mathrm{mmHg}$ dengan standar deviasi 5,991. Hasil ini menunjukan bahwa tekanan darah diastolik lebih tinggi pada klien dengan TIK 
meningkat. Tekanan darah diastolik tidak berhubungan dengan terjadinya peningkatan tekanan intrakranial pada klien stroke hemoragik di RSU Kabupaten Tanggerang dengan nilai $p$ sebesar 0,240 ( $\alpha$ $=0,05)$.

Pada hasil penelitian ini juga mengidentifikasi hubungan faktor-faktor yang mempengaruhi terjadinya tekanan intra kranial pada klien stroke hemoragik yang dijadikan counfonding factor dalam penelitian ini yaitu Kadar HB, Kadar Ht, Kadar GDS, tekanan parsial oksigen $(\mathrm{PaO} 2)$ dan parsial karbondioksida $\left(\mathrm{PaCO}_{2}\right)$, serta kadar kolesterol rata-rata dalam darah.

Hasil analisis univariat didapatkan Kadar HB pada responden rata-rata 13,54 gr/dl dengan standar deviasi 0,781 dan diyakini 95\% kadar hemoglobin responden sebesar 13,08 gr/dl sampai dengan 13,99 gr/dl. Sedangkan kadar HT responden ratarata 40,14\%, dengan standar deviasi 3,697 dan diyakini $95 \%$ kadar hematokrit responden sebesar 38,01\% sampai dengan $42,28 \%$. Kadar GDS responden rata-rata sebesar 140,92 gr/dl dengan standar deviasi sebesar 38,59 dan diyakini 95\% kadar glukosa darah sewaktu responden sebesar 118,64 gr/dl sampai dengan 163,21 gr/dl.

Rata-rata kadar kolesterol responden adalah 154,43 dengan standar deviasi 14,601, dan diyakini 95\% kadar kolesterol responden antara 146,43 sampai dengan
162. Rata-rata tekanan parsial oksigen $\left(\mathrm{PaO}_{2}\right)$ responden adalah 96,83 dengan standra deviasi 5,093, dan diyakkini 95\% nilai $\mathrm{PaO}_{2}$ antara 93,92 sampai dengan 99,76. Sedangkan rata-rata tekanan parsial karbondioksida $\left(\mathrm{PaCO}_{2}\right)$ adalah 34,68 dengan standar deviasi 1,162 dan diyakini 95\% tekanan parsial karbondioksida $\left(\mathrm{PaCO}_{2}\right)$ sebesar 34,19 sampai dengan 35,54 .

Hasil Analisa univariat tersebut, dari kadar Hemoglobin (HB), Kadar Hemotokrit (HT), Kadar gula darah sewaktu (GDS), kadar kolesterol rata-rata dalam darah, dan tekanan parsial karbondioksida $\left(\mathrm{PaCO}_{2}\right)$ masih relatif dalam kondisi normal, dan hasil analisis bivariat dari kadar $\mathrm{HB}, \mathrm{Ht}, \mathrm{GDS}$, Kolesterol dan $\mathrm{PaCO}_{2}$ disimpulkan tidak ada hubungan terhadap TIK didapatkan nilai $p$ lebih besar dari nilai $(\alpha=0,05)$, hanya hasil analisis bivarat pada tekanan partial oksigen $\left(\mathrm{PaO}_{2}\right)$ dinyatakan ada hubungan terhadap TIK pada klien stroke hemoragik dengan didapat nilai $p$ sebesar $0,018(\alpha=0,05)$.

\section{Pembahasan}

Hasil penelitian ini menunjukan bahwa jenis kelamin perempuan lebih banyak mengalami stroke hemoragik, hal ini berbanding terbalik dengan teori bahwa kejadian pada stroke adalah laki-laki (Morton, 2005) tetapi dalam pernyataan tersebut tidak dijelaskan bahwa kejadian 
jenis stroke ada dua yaitu non hemoragik dan hemoragik.

Pada teori lain dijelaskan bahwa penyebab terjadinya stroke dipengaruhi oleh beberapa faktor diantaranya, usia, suku, pola hidup, adanya stressor (Brunner \& Suddart, 2014), dimungkinkan terjadi pada jenis kelamin perempuan pada penelitian ini tetapi tidak ekstrem perpedaannya, hal ini masih cukup rasional teori yang mengatakan bahwa kejadian stroke terjadi pada perempuan karena faktor stressor, pola hidup dan suku tersebut ( (Brunner \& Suddart, 2014).

Berdasarkan hasil penelitian, menurut umur, bahwa umur yang mengalami stroke hemoragik terjadi pada umur 50 tahun, dengan rata-rata umur 48,93 tahun, dari kesimpulan didapatkan bahwa diyakini umur yang mengalami kejadian stroke hemoragik antara umur 34 tahun sampai 58 tahun.

Pada gambaran karakterik umur, dapat disimpulkan bahwa angka kejadian stroke hemoragik, rata-rata umur tersebut menunjukan pergeseran dari dewasa tua ke usia dewasa muda, hal ini memungkinkan karena perubahan pola hidup dan prilaku hidup sehat (Gan, 2008). Hasil analisis dari 14 responden yang diteliti, sebagian besar tidak mengalami peningkatan tekanan intrakranial, yaitu sebanyak 13 dari 14 orang $(92,9 \%)$. Sedangkan yang mengalami peningkatan TIK hanya 1 dari
14 orang $(37,60 \%)$. Hasil analisis lainnya ditemukan bahwa rata-rata suhu tubuh responden adalah $36,71^{\circ} \mathrm{C}$ dan diyakini 95\% suhu tubuh responden dalam rentang 36,37 sampai dengan 37,05, hasil ini dapat diartikan bahwa suhu tubuh responden dalam kategori normal. Sedangkan hubungan suhu tubuh dengan TIK diketahui bahwa rata-rata suhu tubuh pada responden dengan TIK meningkat sebesar $37,6^{\circ} \mathrm{C}$ dan TIK tidak meningkat rata-rata sebesar 36,64 dengan standar deviasi 0,55. Dapat disimpulkan suhu tidak mempengaruhi peningkatan tekanan intrakranial pada pasien stroke hemoragik dengan nilai $\mathrm{P}$ sebesar $0,123(\alpha=0,05)$. Hasil penelitian ini menunjukan bahwa suhu tubuh tidak berpengaruh langsung terhadap perubahan TIK, sedangkan perubahan TIK dalam penelitian ini adalah dengan mengobservasi serta keluhan klien, yaitu dari hasil pemantauan tanda-tanda klinis, yaitu adanya papilla edema, muntah proyektil dan adanya keluhan sakit kepala.

Adapun sesuai hasil penelitian dapat diuraikan sebagai berikut; Tekanan intrakranial (TIK) didefinisikan sebagai tekanan dalam rongga kranial dan biasanya diukur sebagai tekanan dalam ventrikel lateral otak (Joanna Beeckler, 2006). Menurut Morton, et.al tahun 2005, tekanan intrakranial normal adalah 0-15 $\mathrm{mmHg}$. Nilai diatas $15 \mathrm{mmHg}$ dipertimbangkan 
sebagai hipertensi intrakranial atau peningkatan tekanan intrakranial.

Nilai TIK yang tepat diukur dengan menggunakan alat-alat invasif yang digunakan untuk memantau TIK dengan akurat, tetapi dengan kondisi keterbatasan fasilitas tersebut maka pemantauan TIK dapat dilakukan dengan melihat atau memantau kondisi tanda-tanda klinis yang mengindikasikan adanya perubahan TIK. Untuk mengetahui dan memonitor tekanan intrakranial, dapat digunakan metode non invasif atau metode invasif. Metode non invasif meliputi adalah penurunan status neurologi klinis dipertimbangkan sebagai tanda peningkatan TIK. Bradikardi, peningkatan tekanan pulsasi, dilatasi pupil dari normalnya dianggap tanda peningkatan TIK (Thamburaj, Vincent, 2006).

Sesuai dengan teori dan hasil beberapa penelitian bahwa peningkatan suhu tubuh dimungkinkan dapat meningkatkan TIK, tetapi hal ini tidak berpengaruh langsung. Suhu tubuh yang meningkat merupakan interpretasi dari meningkatnya metabolisme tubuh, dengan peningkatan metabolisme tubuh, kebutuhan oksigen juga meningkat, dimana kenaikan suhu satu $\left(1^{0}\right)$ dapat meningkatkan kebutuhan oksigen $10 \%$, sehingga hal ini akan mempengaruhi oksigenasi ke serebral, fluktuasi sirkulasi oksigen mengalami perubahan dan dapat mempengaruhi TIK seiring adanya vasodilasi dan vasospasme pembuluh darah otak sebagai media $\mathrm{CBF}$ (Stocchetti et al. 2013).

Hasil analisis didapatkan rata-rata tekanan darah sistolik sebesar 147,86 mmHg dengan standar deviasi 17,17, dan diyakini $95 \%$ tekanan sistolik dalam rentang 137,94 mmHg sampai dengan $157,77 \mathrm{mmHg}$. Hasil penelitian dapat disimpulkan bahwa tekanan sistolik sebagian besar mengalami peningkatan dari normal. Sedangkan rata-rata tekanan darah sistolik sebesar 92,86 $\mathrm{mmHg}$ dengan standar deviasi 6,11, dan diyakini 95\% tekanan sistolik dalam rentang 89,33 mmHg sampai dengan 96,39 mmHg. Hal ini menunjukkan bahwa tekanan darah dalam rentang normal.

Pada hasil analisis lain bahwa hubungan Tekanan darah dan TIK didapatkan rata-rata tekanan darah sistolik pada pasien dengan TIK meningkat sebesar $190 \mathrm{mmHg}$, dan tekanan darah sistolik pada pasien yang TIK tidak meningkat rata-rata 144,2 mmHg dengan standar deviasi 3,445. Hal ini dapat dilihat bahwa tekanan darah sistolik lebih tinggi pada pasien dengan TIK meningkat. Tekanan darah sistolik berhubungan dengan terjadinya peningkatan tekanan intrakranial pada pasien stroke hemoragik di RSU Kabupaten Tanggerang dengan nilai $p$ sebesar $0,005(\alpha$ $=0,05)$. Sedangkan tekanan diastolik menunjukan rata-rata tekanan darah diastolik pada pasien dengan TIK 
meningkat sebesar $100 \mathrm{mmHg}$, dan tekanan darah diastolik pada pasien yang TIK tidak meningkat rata-rata $92,31 \mathrm{mmHg}$ dengan standar deviasi 5,991. Hal ini dapat dilihat bahwa tekanan darah diastolik lebih tinggi pada pasien dengan TIK meningkat. Tekanan darah diastolik tidak berhubungan dengan terjadinya peningkatan tekanan intracranial pada pasien stroke hemoragik di RSU Kabupaten Tanggerang dengan nilai $p$ sebesar $0,240(\alpha=0,05)$.

Hasil ini menunjukan bahwa ada pengaruh tekanan darah terutama tekanan sistolik terhadap perubahan TIK, yaitu TIK meningkat. Hal ini menunjang teori bahwa perubahan TIK tergantung adanya perubahan dari diameter CSF, Sirkulasi serebral "Cerebral Blood Flow" (CBF) dan abnormalitas intrakranialnya, (Stocchetti et al. 2013). Sedangkan ketika tekanan darah meningkat terjadi kontriksi pembuluh darah dan menurunkan darah ke otak tetapi bila tekanan darah menurun maka pembuluh darah akan dilatasi untuk meningkatkan darah ke otak tentu saja hal ini akan mempengaruhi TIK (Patria et al. 2006).

Hal penting lain adanya perubahan TIK adalah tekanan perfusi serebral/cerebral perfusion pressure (CPP). $C P P$ adalah jumlah aliran darah dari sirkulasi sistemik yang diperlukan untuk memberi oksigen dan glukosa yang adekuat untuk metabolisme otak (Black \& Hawks, 2014). CPP dihasilkan dari tekanan arteri sistemik rata-rata dikurangi tekanan intrakranial, dengan rumus $C P P=M A P-$ ICP. CPP normal berada pada rentang 60$100 \mathrm{mmHg}$. MAP adalah rata-rata tekanan selama siklus kardiak. MAP = Tekanan Sistolik $+2 \mathrm{X}$ tekanan diastolik dibagi 3 . Jika CPP diatas $100 \mathrm{mmHg}$, maka potensial terjadi peningkatan TIK. Jika kurang dari $60 \mathrm{mmHg}$, aliran darah ke otak tidak adekuat sehingga hipoksia dan kematian sel otak dapat terjadi (Morton et.al, 2005). Jika MAP dan ICP sama, berarti tidak ada CPP dan perfusi serebral berhenti, sehingga penting untuk mempertahankan kontrol ICP dan MAP (Black \& Hawks, 2014).

Hasil analisis confounding factor dapat disimpulkan bahwa tidak ada hubungan faktor-faktor tersebut terhadap TIK, hasil ini dimungkinkan karena responden yang diteliti mendapatkan kontrol ketat, yaitu; tidak dalam kondisi stroke berat, hanya stroke ringan, kondisi klien sadar penuh dan tidak ada penyakit penyerta yang memperberat kondisi klien. Sedangkan confounding factor yaitu partial oksigen $\left(\mathrm{PaO}_{2}\right)$ mempunyai hubungan adanya perubahan TIK. Hal ini juga sesuai dengan teori bahwa Stroke perdarahan atau hemoragik adalah stroke yang diakibatkan adanya perdarahan, dapat terjadi dalam intrakranial (jaringan otak), ventrikel atau rongga subarahnoid, (Brunner's \& Suddarth, 2012). Hal-hal yang berperan dalam pengendalian aliran darah antara lain 
autoregulasi, kontrol metabolik dan neural. Viskositas darah berperan dalam kehidupan jaringan otak, karena makin tinggi viskositas darah semakin rendah kecepatan aliran darah keotak sehingga suplai oksigen berkurang. Otak mendapat 20\% dari curah jantung artinya aliran darah secara global serebral dialiri volume darah per menit per 100 gram jaringan otak, rata-rata bila terjadi peningkatan tekanan kadar $\mathrm{CO}_{2}$ (pCO2) satu (1) $\mathrm{mmHg}$ dimungkinkan terjadi peningkatan darah 1-2 cc pada CBF dan ini akan terjadi perubahan peningkatan volume darah di otak (Black \& Hawk, 2014).

Beberapa faktor risiko penyebab stroke antara lain; gaya/kebiasaan hidup, hipertensi, kolesterol meningkat, aterosklerosis, gangguan jantung, diabetus mellitus (Black \& Hawk, 2014). Volume perdarahannya sendiri merupakan hal penting sebagai prediktor perkembangan klien, perdarahan dapat juga terjadi akibat rupture aneurisme atau malformasi pembuluh darah, (Brunner's \& Suddarth, 2012).

Walaupun dalam hasil penelitian yang dilakukan oleh Stefan Schwarz, Dimitrios Georgiandis, Alfred Aschoff and Stefan Schweb yang berjudul "Effect of body position (head of bed elevation) on intracranial pressure and cerebral perfusion in patients with large haemorraghic stroke". Penelitian ini dilakukan pada 18 pasien stroke Iskemik akut yang dirawat di neurocritical care unit. Indikator evaluasi adalah nilai GCS, pupil, tekanan darah, denyut nadi, frekuensi pernapasan, suhu tubuh, tekanan intrakranial, MAP (mean arteri pressure), Middle cerebral artery (MCA) peak mean flow velocity $\left(\mathrm{V}_{\mathrm{m}} \mathrm{MCA}\right)$, tekanan perfusi serebral. Semua pasien terpasang intubasi, ventilator, terpasang monitor tekanan TIK, MAP dan MCA peak mean flow velocity dengan intracranial ultra sound.

Pada hasil penelitian telah dianalisis bahwa tidak ada hubungan temperature/suhu tubuh, tekanan darah terhadap TIK pada klien stroke hemoragik, tetapi tekanan darah sistolik berpengaruh terhadap TIK, yaitu terjadi peningkatan TIK. Pada saat TIK meningkat pada titik dimana kemampuan otak untuk menyesuaikan diri telah mencapai batasnya, fungsi saraf yang terganggu dimanifestasikan dengan perubahan tingkat kesadaran dan respirasi serta respon vasomotor abnormal. Tanda paling dini peningkatan TIK adalah letargi, lambatnya bicara dan respon verbal, (Honig et al.2015).

\section{Kesimpulan}

Berdasarkan hasil penelitian dapat disimpulkan bahwa insiden stroke hemoragik paling banyak terjadi pada umur antara 34-58 tahun, dan kejadian stroke hemoragik terbanyak pada jenis kelamin 
perempuan. Penelitian ini telah mendapatkan hasil bahwa perubahan TIK dapat dilihat dari tanda-tanda klinis klien, tanda-tanda klinis tersebut, adalah; muntah proyektil, sakit kepala dan adanya papilla edema dimana bila terjadi papilla edema saja dapat diartikan bahwa terjadi peningkatan TIK. Hasil penelitian didapatkan bahwa tidak ada hubungan yang bermakna dari perubahan suhu tubuh terhadap TIK pada pasien dengan stroke hemoragik. Hubungan Tekanan darah dan TIK didapatkan bahwa tidak ada hubungan yang bermakna dari perubahan Tekanan darah diastole terhadap TIK pada pasien dengan stroke hemoragik, tetapi perubahan Tekanan darah systole menunjukan ada hubungan yang bermakna terhadap TIK. Hasil lain penelitian ini menunjukan bahwa kadar $\mathrm{Hb}$ darah, kadar $\mathrm{Ht}$ darah Kadar GDS, Kadar Kolesterol darah, kadar $p \mathrm{CO}_{2}$ tidak ada hubungan bermakna terhadap perubahan TIK pada klien stroke hemoragik, sedangkan kadar $\mathrm{pO}_{2}$. Menunjukan ada hubungan bermakna terhadap perubahan TIK pada klien stroke hemoragik. Hasil penelitian ini merekomendasikan bahwa pentingnya pemantauan atau observasi dilakukan untuk klien dengan stroke hemoragik untuk deteksi dini adanya perubahan TIK.

\section{Daftar Pustaka}

AHA/ASA, 2015. Gudelines stroke 2015; Stroke. 2015;46:000-000, American Heart Association, Inc. http:// stroke.ahajournals.org.

Black, Joice. M., \& Hawk, Jane. H.2014. Medical Surgical Nursing; clinical management for positive outcomes. $\left(8^{\text {th }}\right.$ Ed. $)$, St. Louis: Elsevier. Inc

Ceulemans et al, 2010. The dual role of the neuroinflammatory response after ischemic stroke: modulatory effects of hypothermia. Journal of Neuroinflammation 2010, 7:74. Diambil 12 Juni 2016 dari http://www.jneuroinflammation.co $\mathrm{m} /$ content/7/1/74

Ginsberg L, 2008. Neurologi; Lecture Notes $\left(8^{\text {th }}\right.$ ed.). alih bahasa Wardhani. Malang; Penerbit Erlangga.

Helleberg et al. 2014. Mechanisms, predictors and clinical impact of early neurological deterioration: the protocol of the Trondheim early neurological deterioration study: BMC Neurology 2014, 14:201, diambil pada 13 Juni 2016 dari http://www.biomedcentral.com/147 $1-2377 / 14 / 201$.

Honig et al. 2015. Central fever in patients with spontaneous intracerebral hemorrhage: predicting factors and impact on outcome BMC Neurology (2015) 15:6 DOI 10.1186/s12883015-0258-8.

Joyce LeFever, 2009. Pemeriksaan Laboratorium dan diagnostik dengan implikasi keperawatan; Terjemahan editor Ester M: Jakarta; EGC.

Kostić, 2011. Severe brain injuries: correlation between survival and Intrakranial hypertension. UDC: 
616.714.1-001.5:616.12-008.331.1, doi:10.5633/amm.2011.0302

Patria et.al, 2006. Cerebrovascular dynamics with head of bed elevation in patients with mild or moderate vasospasme after aneurisma subarachnoid hemoragik. American Journal of Critical care. Vol. 56.

Pollit, D.F., \& Beck, C.T. 2006. Essentials of Nursing Research : Methods, Appraisal, and utilization. (6 ${ }^{\text {th }}$ Ed.). Philadelphia: Lippincott Williams \& Walkins.

Riskesdas, 2007, Riset Kesehatan Dasar Tahun 2007, Kemenkes; Jakarta

Riskesdas, 2013, Riset Kesehatan Dasar Tahun 2013, Kemenkes; Jakarta

Robert N Gan, 2008. The Stroke Clinician's Handbook; A Practical Guide to the care of stroke patient. Singapore: world Scientific Publishing Co. Pte. Ltd.

Sunardi, 2011. Pengaruh pemberian posisi kepala flat 0 derajat dan elevasi kepala 30 derajat terhadap tekanan intrakranial pada pasien stroke iskemik di RSCM jakarta; Jurnal Madya Poltekkes Kemenkes Jakarta III edisi, Vol.10, No.1,Juni 2011.

Smletzer, S.C., \& Bare, B.G. 2014. Brunner \& Suddarth's: Textbook of Medical Surgical Nursing. Philadelphia: Lippincott.

Stocchetti et al. 2013. Clinical review: Neuromonitoring - an update: Critical Care 2013, 17:201,diambil pada 13 Juni 2016 dari http://ccforum.com/content/17/1/20 $\underline{1}$ 